\title{
JEJAK ALUMNI JURUSAN PGMI IAIN SYEKH NURJATI CIREBON DAN RESPON PENGGUNA (STAKEHOLDER) TERHADAP KOMPETENSI DAN KINERJANYA
}

\author{
Tamsik Udin \\ *Dosen Jurusan PGMI FITK IAIN Syekh Nurjati Cirebon
}

\begin{abstract}
ABSTRAK
Jurusan Pendidikan Guru Madrasah Ibtidaiyah (PGMI) Strata Satu (S1) di Fakultas Ilmu Tarbiyah dan Keguruan (FITK) Institut Agama Islam Negeri (IAIN) Syekh Nurjati Cirebon berdiri sejak tahun 2007. Ijin pendirian dari Kementerian Agama RI dalam bentuk SK Dirjen Pendidikan Tinggi Islam nomor: Dj.I/257/2007 tanggal 10 Juli 2007 tentang Ijin Operasional. Alumni Jurusan PGMI yang ada selama ini belum dapat mengisi formasi guru MI yang berada di wilayah III Cirebon dan bahkan belum merata, apalagi untuk di luar wilayah Cirebon.

Tujuan Tracer Study ini adalah untuk :1.mengetahui keberadaan alumni PGMI serta menjalin komunitas seara kontinue.2. Mengidentifikasi profil kompetensi dan keterampilan lulusan. 3. Mengetahui relevansi pelaksanaan kurikulum dan kebutuhan pasar kerja. 4. Memenuhi Kriteria Akreditasi/sertifikasi Jurusan PGMI.5. Memenuhi persyaratan bantuan penelitian tahun 2014.

Millington (2006), "tracer study is an impact assessment toll where the impact on target groups is traced back to specific elements of programme so that effective and ineffective project components may be identified" (sebuah metode untuk menelusuri informasi mengenai Alumni).

Metode dalam penelitian inia dalah deskriptif. Dengan metode deskriptif ini juga diselidiki kedudukan (status) fenomena atau factor dan melihat hubungan antara satu factor dengan factor yang lain. Karenanya, metode deskriptif juga dinamakan studi status atau disebut juga survey normative. Prespektif waktu yang dijangkau dalam penelitian deskriptif, adalah waktu sekarang, atau sekurang-kurangnya jangka waktu yang masih terjangkau dalam ingatan responden.

Hasil penelitian ini menunjukkan bahwa Keberadaan alumni Jurusan PGMI tahun sejak tahun 2012 dan tahun 2013 belum merata di daerah wilayah III Cirebon. Pkeberadaan rofil kompetensi alumni Jurusan PGMI Pekerjaan Hampir setengahnya (40\%) responden sudah bekerja di sekolah swasta, Penyelenggaraan Pengajaran di PGMI direspon oleh Hampir setengahnya (44,4\%), Profil Stakeholder Lebih dari setengahnya (65.0\%) stakeholder sebagai tempat bekerja alumni PGMI adalah swasta.
\end{abstract}

Kata Kunci : Alumni, Tracer Study, Stakeholder 


\section{A. Latar Belakang Masalah}

Jurusan Pendidikan Guru Madrasah Ibtidaiyah (PGMI) Strata Satu (S1) di Fakultas Ilmu Tarbiyah dan Keguruan (FITK) Institut Agama Islam Negeri (IAIN) Syekh Nurjati Cirebon berdiri sejak tahun 2007 dengan SK Dirjen Pendidikan Tinggi Islam nomor: Dj.I/257/2007 tanggal 10 Juli 2007 tentang Izin Operasional untuk Jurusan PGMI S1 dengan quota dua kelas, masing-masing kelas berjumlah 35 orang mahasiswa. Program Ini merupakan pengembangan dari Jurusan PGMI Diploma Dua yang berdiri sejak tahun 2004

Tujuh tahun Jurusan PGMI di IAIN Syekh Nurjati Cirebon sudah meluluskan 234 orang Sarjana Pendidikan Islam (S.PdI) tetapi belum pernah ada kegiatan kumpul alumni PGMI dan bahkan data alumni pgmi yang ada di Jurusan PGMI saat ini hanya ada dalam buku wisuda dengan identitas yang kurang lengkap.

Alumni Jurusan PGMI yang ada selama ini beum dapat mengisi formasi guru MI yang berada di wilayah III Cirebon, apa lagi untuk di luar wilayah Cirebon. Sebagai data bahwa MI sebagai stakeholder yang ada di wilayah III Cirebon - Kota dan Kabupaten Cirebon, Kabupaten Kuningan, Kabupaten Majalengka dan Kabupaten indramayu- tahun 2013 itu berjumlah 379 Madrasah, terdiri dari : 354 Madrasah swasta dan 25 Madrasah Negeri. Hal ini belum termasuk madrasah yang berada di wilayah Kabupaten Brebes, Kabupaten Tegal dan Kabupaten Subang yang relatif banyak mensuplay mahasiswa ke jurusan PGMI IAIN Cirebon.

Respon stakeholder dari alumni Jurusan PGMI IAIN Syekh Nurjati Cirebon selama ini belum pernah dilakukan penelitian secara spesifik. Informasi dari para stakeholder ini sangat penting, terutama untuk melihat sejauh mana masyarakat atau stakeholder memandang jurusan PGMI IAIN 
Syekh Nurjati Cirebon sebagai pencetak tenaga ahli, terutama di bidang Guru pendidikan Madrasah. Repson yang masuk dari masyarakat pengguna juga akan bermanfaat bagi Jurusan PGMI sebagai sarana untuk mawas diri agar lebih bias meningkatkan mutu pendidikan, kualitas layanan, maupun kualitas tenaga ahli yang dihasilkannya.

Tracer study untuk stakeholder alumni Jurusan PGMI merupakan salah satu studi empiris yang diharapkan menyediakan informasi untuk mengevaluasi hasil pendidikan di Jurusan PGMI. Informasi ini digunakan untuk pengembangan lebih lanjut dalam menjamin kualitas pendidikan. Dengan kegiatan tracer study ini diharapkan Jurusan mendapatkan informasi indikasi kekurangan pelaksanaan program studi dan menyediakan dasar-dasar pelaksanaan perencanaan dimasa depan. Demikian pula infromasi terhadap pengetahuan dan keahlian yang relevan. Para alumni diharapkan juga dapat memberikan penilaian kondisi dan ketentuan belajar yang mereka alami masa belajar dikaitkan dengan dunia kerja yang mereka hadapi. Bagi para pengguna, hasil kajian ini diharapkan dapat bermanfaat untuk menjadi salah satu pertimbangan apakah mereka akan menggunakan alumni PGMI di Madrasahnya. Bagi pengelola (Jurusan PGMI),diharapkan dapat bermanfaat untuk menentukan strategi dan orientasi pendidikan, melakukan perbaikan konsep maupun teknis penyelenggaraan pendidikan dan pembelajaran sehingga lulusan semakin menjadi lebih baik dalam kapasitas intelektualitasnya, keterampilan maupun akhlak dan kepribadiannya.

Trace Study merupakan salah satu kegiatan penelitian yang perlu dilakukan secara rutin oleh Pergururn Tinggi untuk mengetahui perubahan dan kebutuhan akan kemampuan dan kapabilitas lulusan yang sesuai dengan kondisi dunia praktis yang kompleks melalui pendapat para alumni.

Menurut Millington (2006), "tracer study is an impact assessment toll where the impact on target groups is traced back to specific elements of 
programme so that effective and ineffective project components may be identified" (sebuah metode untuk menelusuri informasi mengenai alumni).

Hasil tracer study untuk stakeholder alumni PGMI ini juga diharapkan dapat dipakai sebagai bahan pertimbangan dalam pengembangan kualitas proses pembelajaran dan evalausi pembelajaran serta pengembangan manajemen pendidikan. 
Data dosen tetap yang bidang keahliannya sesuai dengan bidang PS:

\begin{tabular}{|c|c|c|c|c|c|c|c|}
\hline No & $\begin{array}{l}\text { Nama Dosen } \\
\text { Tetap }\end{array}$ & $\begin{array}{l}\text { NIP/ } \\
\text { NIDN }\end{array}$ & Tgl. Lahir & $\begin{array}{l}\text { Jabata } \\
\text { n } \\
\text { Akade } \\
\text { mik }\end{array}$ & $\begin{array}{l}\text { Gelar } \\
\text { Akade } \\
\text { mik }\end{array}$ & $\begin{array}{l}\text { Pendidikan S1, } \\
\text { S2, S3 dan Asal } \\
\text { Universitas }\end{array}$ & $\begin{array}{l}\text { Bidang Keahlian } \\
\text { untuk Setiap } \\
\text { Jenjang Pendidikan }\end{array}$ \\
\hline (1) & (2) & (3) & (4) & (5) & (6) & (7) & (8) \\
\hline 1 & $\begin{array}{l}\text { Drs. Aceng } \\
\text { Jaelani, M. } \\
\text { Ag }\end{array}$ & $\begin{array}{l}196509 \\
30 \\
199402 \\
1001\end{array}$ & $\begin{array}{l}\text { Majalengka, } \\
30 \\
\text { September } \\
1965\end{array}$ & $\begin{array}{l}\text { Lektor } \\
\text { Kepala }\end{array}$ & $\begin{array}{l}\text { Drs., } \\
\text { M. Ag }\end{array}$ & $\begin{array}{l}\text { S1 IAIN Cirebon } \\
\text { S2 UIN Bandung }\end{array}$ & $\begin{array}{l}\text { Dasar-Dasar } \\
\text { Pendidikan Islam }\end{array}$ \\
\hline 2 & $\begin{array}{l}\text { Patimah, } \\
\text { M.Ag }\end{array}$ & $\begin{array}{l}197705 \\
291997 \\
032001\end{array}$ & $\begin{array}{l}\text { Indramayu, } \\
\text { 29Mei1973 }\end{array}$ & $\begin{array}{l}\text { Lektor } \\
\text { Kepala }\end{array}$ & M.Ag & $\begin{array}{l}\text { S1 IAIN Cirebon } \\
\text { S2 IAIN Bandung }\end{array}$ & Kurikulum PAI \\
\hline 3 & $\begin{array}{l}\text { Dr. } \mathrm{Hj} . \\
\text { Latifah, MA }\end{array}$ & $\begin{array}{l}195602 \\
25 \\
198602 \\
2001\end{array}$ & $\begin{array}{l}\text { Cirebon, } 25 \\
\text { Pebruari } \\
1956\end{array}$ & $\begin{array}{l}\text { Lektor } \\
\text { Kepala }\end{array}$ & $\begin{array}{l}\text { Dra., } \\
\text { MA }\end{array}$ & $\begin{array}{l}\text { S1 Unswagati } \\
\text { Cirebon.S2 UMY } \\
\text { Yogyakarta. S3 } \\
\text { UPI }\end{array}$ & Ilmu Pendidikan \\
\hline
\end{tabular}




\begin{tabular}{|c|c|c|c|c|c|c|c|}
\hline 4 & $\begin{array}{l}\text { Dr. Uci } \\
\text { Sanusi, M. Pd }\end{array}$ & $\begin{array}{l}195207 \\
19 \\
197903 \\
1004\end{array}$ & $\begin{array}{l}\text { Kuningan, } \\
\text { 19 Juli } 1952\end{array}$ & $\begin{array}{l}\text { Lektor } \\
\text { Kepala }\end{array}$ & $\begin{array}{l}\text { Drs, M. } \\
\text { Pd }\end{array}$ & $\begin{array}{l}\text { S1 S2 UNSIL } \\
\text { Tasikmalaya. S3 } \\
\text { UNINUS }\end{array}$ & Metode Pengajaran \\
\hline 5 & $\begin{array}{l}\text { Dr. Tamsik } \\
\text { Udin, M. Pd }\end{array}$ & $\begin{array}{l}196302 \\
07 \\
199203 \\
1002\end{array}$ & $\begin{array}{l}\text { Banyumas, } \\
7 \text { Pebruari } \\
1963\end{array}$ & $\begin{array}{l}\text { Lektor } \\
\text { Kepala }\end{array}$ & $\begin{array}{l}\text { Drs., } \\
\text { M. Pd }\end{array}$ & $\begin{array}{l}\text { S1 IKIP Bandung } \\
\text { S2 UPI Bandung. } \\
\text { S3 UPI Bandung }\end{array}$ & $\begin{array}{l}\text { Perencanaan } \\
\text { Pengajaran }\end{array}$ \\
\hline 6 & $\begin{array}{l}\text { Drs. Moh. } \\
\text { Masnun, M. } \\
\text { Pd }\end{array}$ & $\begin{array}{l}196107 \\
101986 \\
031024 \\
/ \\
201007 \\
6101\end{array}$ & $\begin{array}{l}\text { Cirebon, } 10 \\
\text { Juli } 1961\end{array}$ & $\begin{array}{l}\text { Lektor } \\
\text { Kepala }\end{array}$ & $\begin{array}{l}\text { Drs., } \\
\text { M. Pd }\end{array}$ & $\begin{array}{l}\text { S1 IKIP Bandung } \\
\text { S2 UHAMKA } \\
\text { Jakarta }\end{array}$ & PTK \\
\hline 7 & $\begin{array}{l}\text { Dr. Sopidi, } \\
\text { S.Ag., SS., } \\
\text { M.A. }\end{array}$ & $\begin{array}{l}196911 \\
02 \\
199903 \\
1002\end{array}$ & $\begin{array}{l}\text { Indramayu/ } \\
02 / 11 / 1969\end{array}$ & Lektor & $\begin{array}{l}\text { S.Ag., } \\
\text { M.A }\end{array}$ & $\begin{array}{l}\text { S1 IAIN Bandung, } \\
\text { S2 UMY S3 } \\
\text { UMY. }\end{array}$ & $\begin{array}{l}\text { Psikologi } \\
\text { Perkembangan }\end{array}$ \\
\hline
\end{tabular}




\begin{tabular}{|c|c|c|c|c|c|c|c|}
\hline 8 & $\begin{array}{l}\text { Dra. } \\
\text { Mukhlisoh, } \\
\text { M. Pd }\end{array}$ & $\begin{array}{l}196509 \\
12 \\
199803 \\
2002\end{array}$ & $\begin{array}{l}\text { Brebes, } 12 \\
\text { September } \\
1965\end{array}$ & Lektor & $\begin{array}{l}\text { Dra, M, } \\
\text { Mpd }\end{array}$ & $\begin{array}{l}\text { S1 IAIN SGD di } \\
\text { Cirebon } \\
\text { S2 UNSOED } \\
\text { Purwokerto }\end{array}$ & $\begin{array}{l}\text { Administrasi } \\
\text { Pendidikan }\end{array}$ \\
\hline 9 & $\begin{array}{l}\text { Akhmad } \\
\text { Busyaeri, M. } \\
\text { Pd }\end{array}$ & $\begin{array}{l}197201 \\
13 \\
200501 \\
1005\end{array}$ & $\begin{array}{l}\text { 13 Januari } \\
1972\end{array}$ & Lektor & $\begin{array}{l}\text { S. Pd, } \\
\text { M. Pd.I }\end{array}$ & $\begin{array}{l}\text { S1 STAI Cirebon } \\
\text { S2 IAIN Surabaya }\end{array}$ & Akhlak \\
\hline 10 & $\begin{array}{l}\text { Idah Faridah } \\
\text { Laily, M.Pd }\end{array}$ & $\begin{array}{l}198210 \\
212011 \\
012015\end{array}$ & $\begin{array}{l}\text { Ciamis, } 21 \\
\text { Oktober } \\
1982\end{array}$ & Lektor & M.Pd & $\begin{array}{l}\text { S1 IAINBandung } \\
\text { S2 UPI }\end{array}$ & PENDAS \\
\hline 11 & $\begin{array}{l}\text { Sybli Maufur, } \\
\text { M.Pd. }\end{array}$ & $\begin{array}{l}197405 \\
28 \\
200801 \\
1011\end{array}$ & $\begin{array}{l}\text { Cirebon, } 28 \\
\text { Mei } 1974\end{array}$ & Lektor & M.Pd. & $\begin{array}{l}\text { S1 STAIN CRB } \\
\text { S2 UPI BDG }\end{array}$ & Bahasa Indonesia \\
\hline 12 & $\begin{array}{l}\text { Atikah } \\
\text { Syamsi, } \\
\text { M.Pdi. }\end{array}$ & $\begin{array}{l}198404 \\
132011 \\
012010\end{array}$ & $\begin{array}{l}13 \text { April } \\
1984\end{array}$ & Lektor & M.Pd & $\begin{array}{l}\text { S1 UIN Jogyakarta } \\
\text { S2, UIN } \\
\text { Jogyakarta }\end{array}$ & PGMI \\
\hline
\end{tabular}




\begin{tabular}{|l|l|l|l|l|l|l|l|}
\hline 13 & Dwi Anita & 197703 & & & S1, IAIN Cirebon & \\
Alfiani, & 102007 & $\begin{array}{l}10 \text { Maret } \\
\text { M.PdI }\end{array}$ & 012020 & Lektor & M.PdI & S2 IAIN Cirebon & Al-Quran \\
\hline \multirow{2}{*}{14} & $\begin{array}{l}\text { Drs.H.S.Buny } \\
\text { amin, M.Pd }\end{array}$ & 031007 & 06 Juli 1958 & Lektor & M.Pd & S1 IAIN Cirebon & MSI \\
\hline
\end{tabular}

Keadaan mahasiswa

\begin{tabular}{|c|c|c|}
\hline TH AKADEMIK & SEMESTER & JUMLAH \\
\hline 2012 & I & 52 \\
\hline 2013 & I & 56 \\
\hline 2014 & I & 83 \\
\hline
\end{tabular}




\section{B. Tujuan Tracer Study}

1. Mengetahui keberadaan alumni PGMI serta menjalin komunitas seara kontinue.

2. Mengidentifikasi profil kompetensi dan keterampilan lulusan.

3. Mengetahui relevansi pelaksanaan kurikulum dan kebutuhan pasar kerja.

4. Memenuhi Kriteria Akreditasi/sertifikasi Jurusan PGMI.

5. Memenuhi persyaratan bantuan penelitian tahun 2014.

I. Pelaksanaan

Jadual Pelaksanaan tracer study

\begin{tabular}{|c|l|l|}
\hline No & \multicolumn{1}{|c|}{ Kegiatan } & \multicolumn{1}{c|}{ Waktu } \\
\hline 1 & Rapat kordinasi & Juni 2014 \\
\hline 2 & Pembuatan Proposal tracer study & Juli 2014 \\
\hline 3 & Pelaksanaan tracer study & $\begin{array}{l}\text { Juli sd September } \\
2014\end{array}$ \\
\hline 4 & Rapat kordinasi dan monev & 13 Agustus 2014 \\
\hline 5 & Penyusunan Laporan & 21 Agustus 2014 \\
\hline 6 & Progres raport & 10 september 2014 \\
\hline 7 & Progres raport & 2 Oktober 2014 \\
\hline 8 & Final raport & 28 Oktober 2014 \\
\hline
\end{tabular}

Metode tracer study yang digunakan :

a. Metode off line ( mengisian angket) sebanyak 45 orang alumni

b. Metode on line (melalui situs www.iaincirebon.ac.id). belum dilaksanakan.

\section{Hasil Penelitian dan Pembahasan}

Jumlah responden adalah $30 \%$ X 150 : 45 orang.

Teknik pengumpulan data dari responden- alumni PGMI dan stakeholderdengan menggunakan angket. Angket untuk alumni dengan dua indikator yaitu: Pekerjaan responden dan Akademik. Angket untuk stakeholder indikatornya adalah : Kriteria dan prosedur penerimaan tenaga kerja, kinerja lulusan Jurusan PGMI, Hasilnya dipaparkan dalam tabel dan hasilnya ditafsirkan dengan pedoman sebagai berikut : 


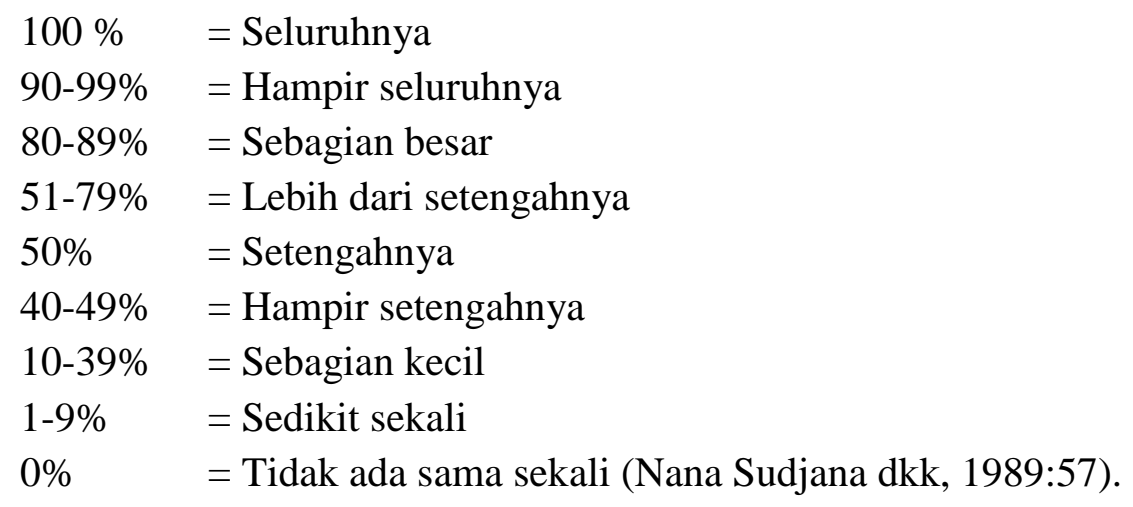

\section{Hasil Penelitian}

\section{a. Profil Alumni}

\begin{tabular}{|c|c|c|}
\hline \multicolumn{3}{|c|}{ Profil Responden } \\
\hline \multicolumn{3}{|c|}{ Pekerjaan } \\
\hline 1 & $\begin{array}{l}\text { Hampir setengahnya }(40,0 \%) \\
\text { responden mendapatkan pekerjaan } \\
\text { kurang dari } 3 \text { bulan setelah wisuda. } \\
\text { Sebagian kecil }(15,6 \%) \text { responden } \\
\text { mendapatkan pekerjaan lebih dari } 3 \\
\text { bulan setelah lulus. Sebagian kecil } \\
(37,8 \%) \text { responden sudah bekerja } \\
\text { sebelum lulus. Sedikit sekali }(2,2 \%) \\
\text { responden mendapatkan pekerjaan 6- } \\
12 \text { bulan setelah lulus. Sedikit } \\
\text { sekali (4,4\%) responden } \\
\text { mendapatkan pekerjaan } 1-2 \text { tahun } \\
\text { setelah lulus. }\end{array}$ & 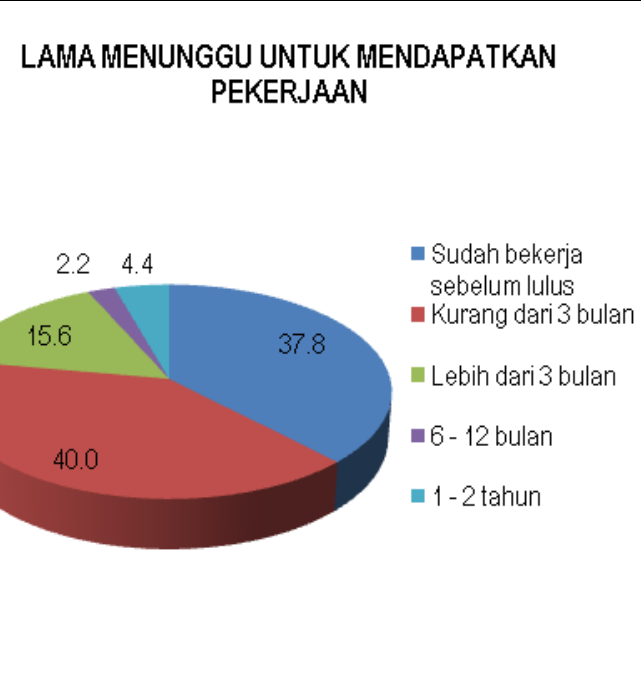 \\
\hline
\end{tabular}




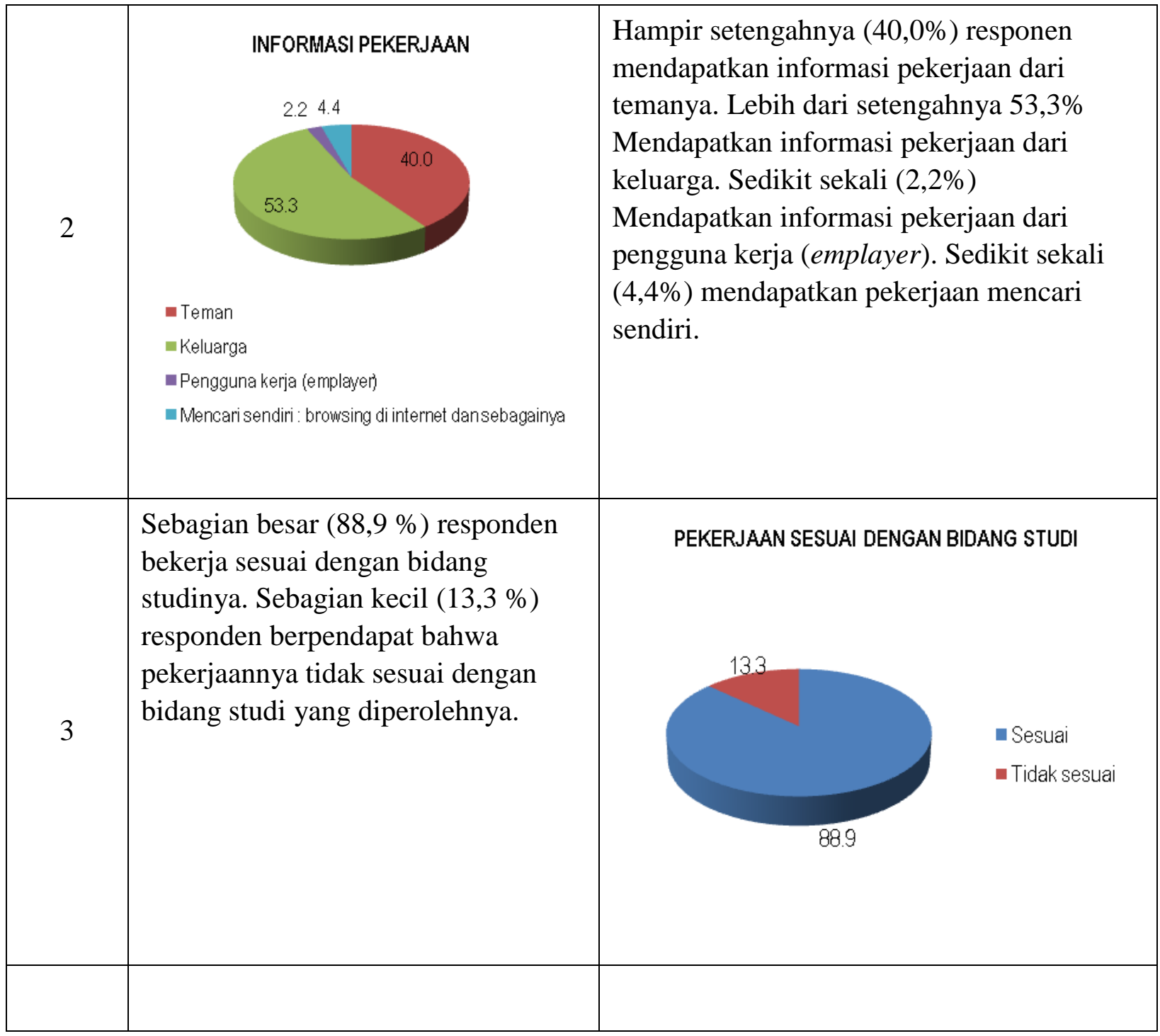




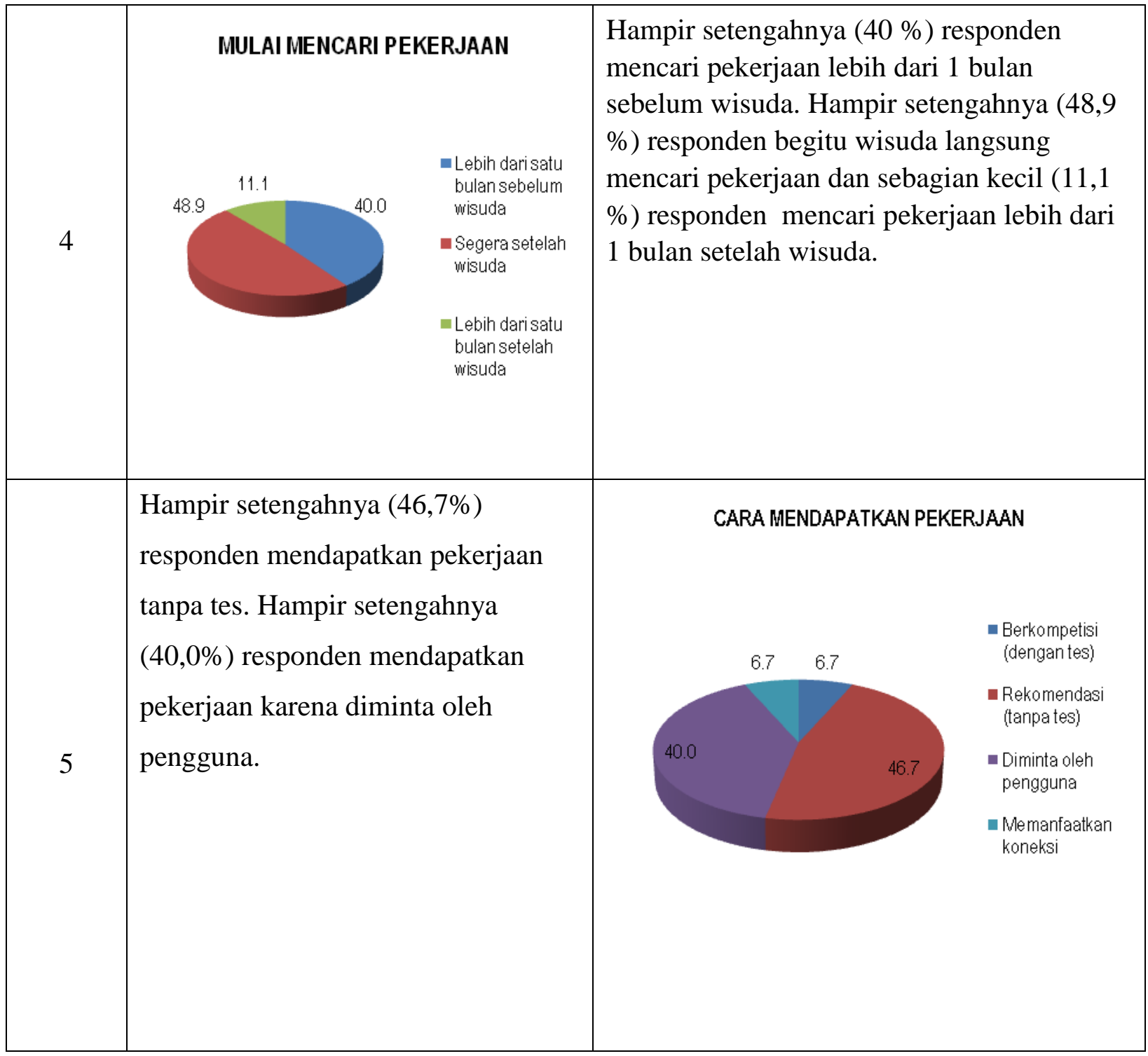




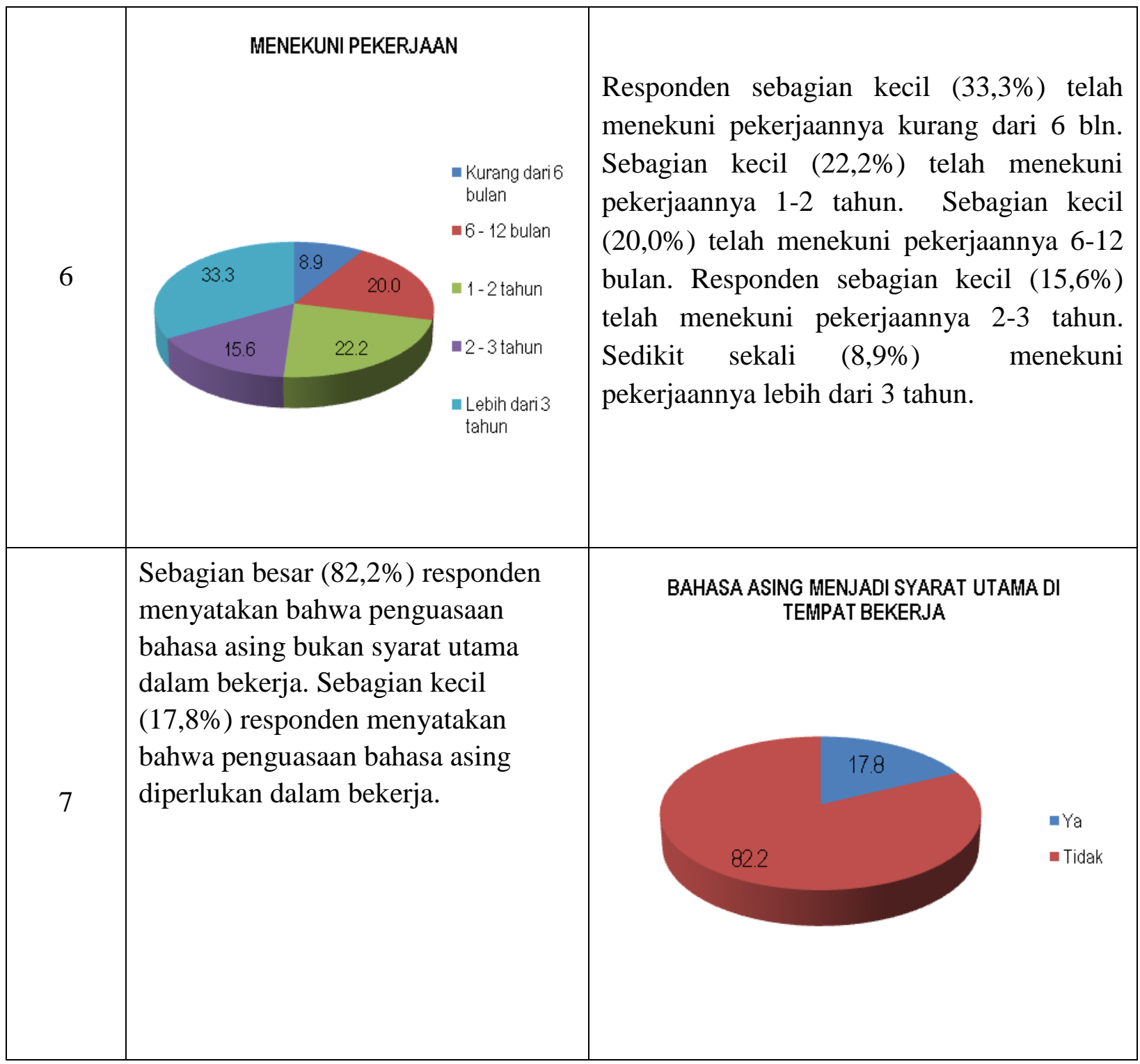




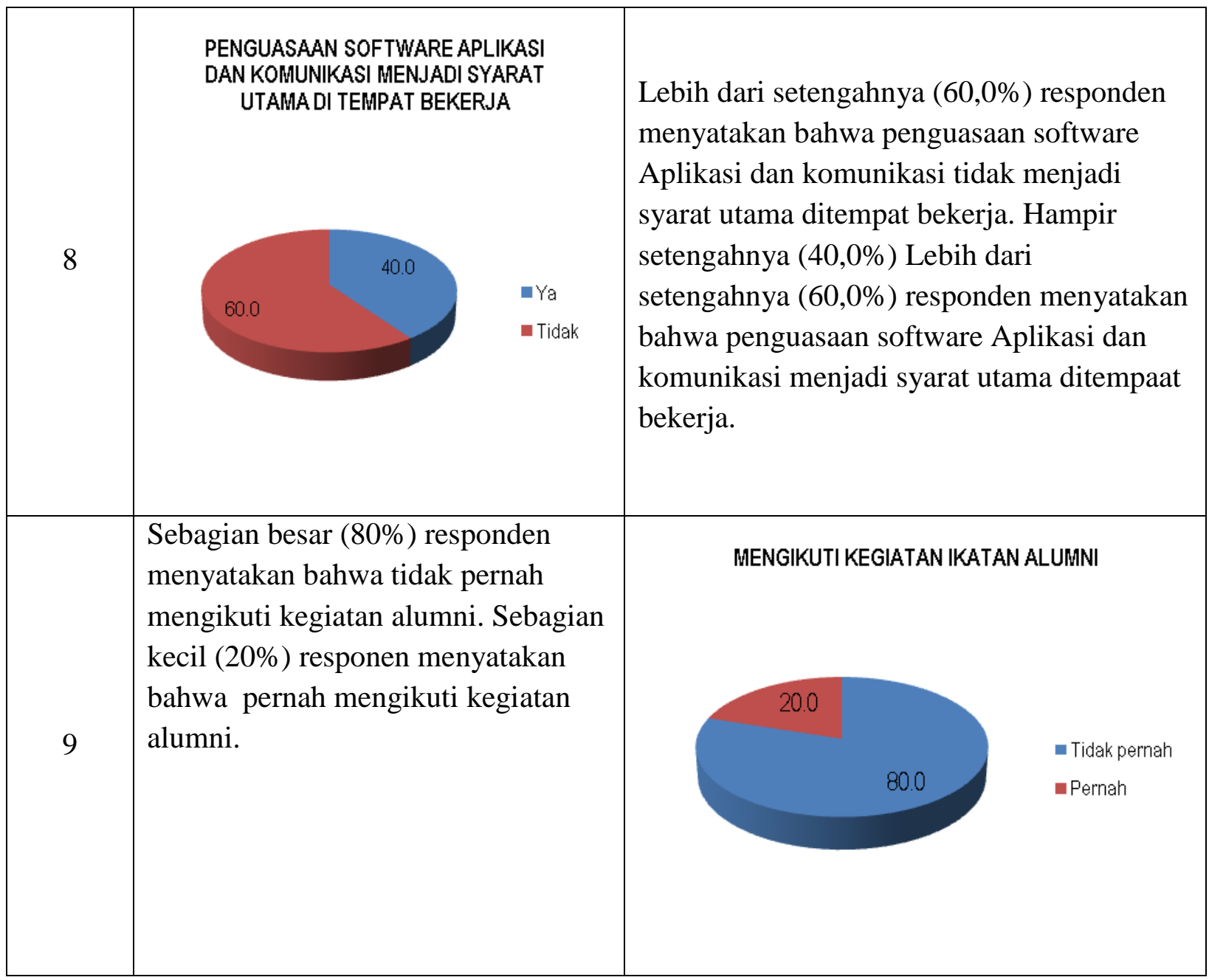




\section{b. Profil Stakeholder}

\begin{tabular}{|c|c|c|}
\hline \multicolumn{3}{|c|}{ Profil Stakeholder } \\
\hline 1 & 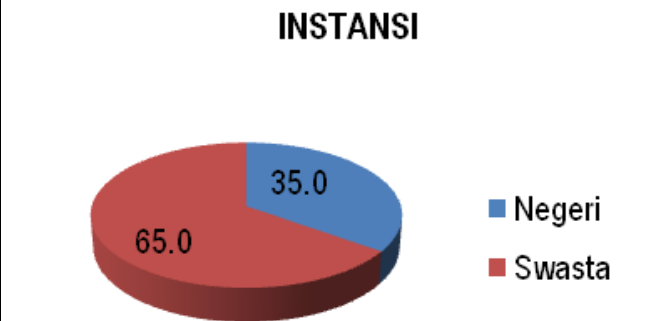 & $\begin{array}{l}\text { Lebih dari setengahnya (65.0\%) stakeholder } \\
\text { sebagai tempat bekerja alumni PGMI adalah } \\
\text { swasta. hanya sebagian kecil }(35,0 \%) \\
\text { stakeholder yang sebagai tempat bekerja } \\
\text { alumni adalah negeri. }\end{array}$ \\
\hline 2 & $\begin{array}{l}\text { Lebih dari setengahnya ( } 65 \%) \text { tenaga } \\
\text { kerja yang ada di stakeholder } \\
\text { berjumlah antara } 10 \text { sampai } 50 \\
\text { orang. Sebagian kecil }(35 \%) \text { tenaga } \\
\text { kerja yang ada di stakeholder } \\
\text { berjumlah sekitar } 10 \text { orang }\end{array}$ & $\begin{array}{l}\text { JUMLAH TENAGA KERJA } \\
\qquad \begin{aligned} & =<10 \text { org } \\
& \\
& \end{aligned} \quad>10-50 \text { org }\end{array}$ \\
\hline
\end{tabular}




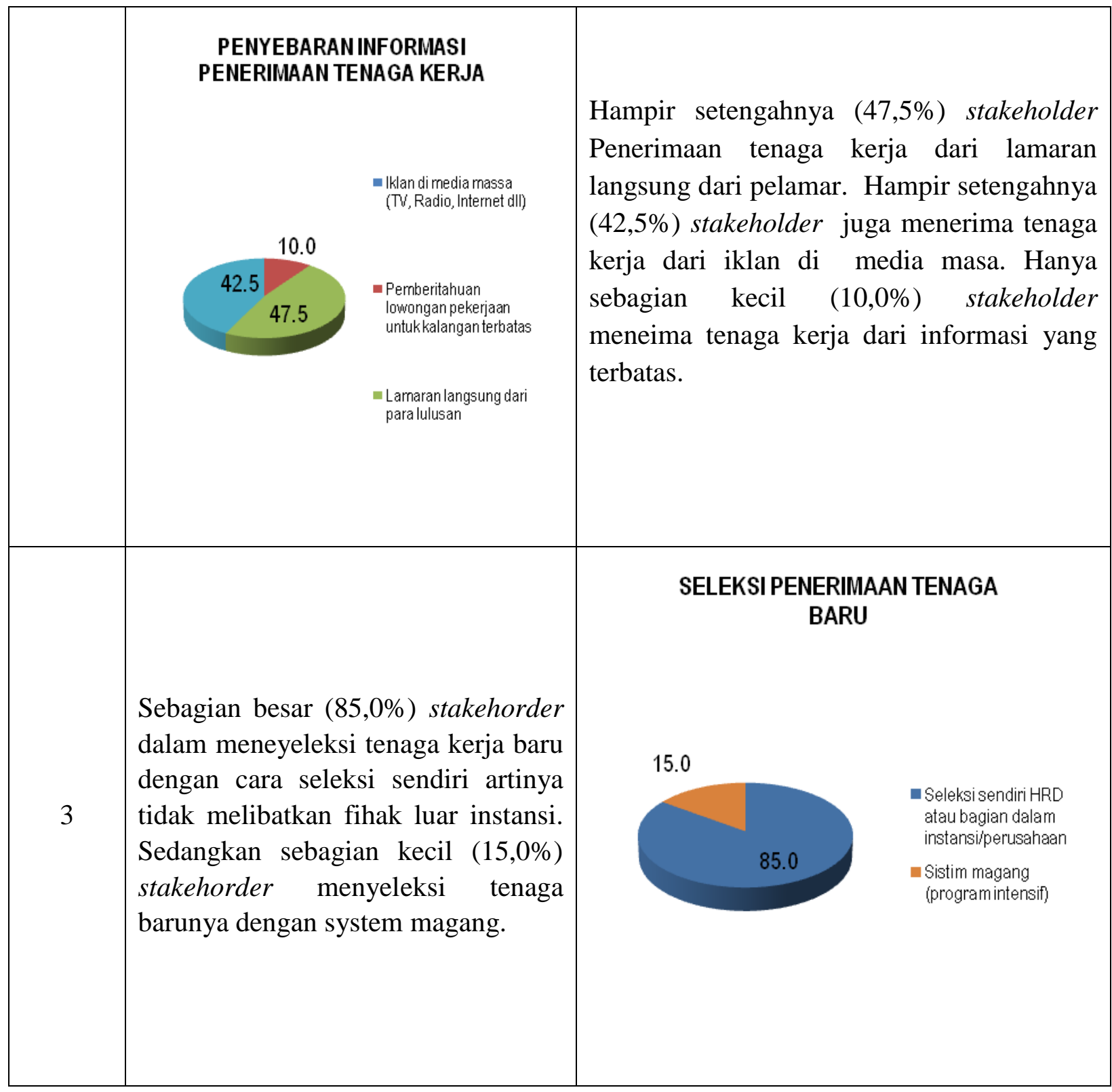




\begin{tabular}{|c|c|c|}
\hline & $\begin{array}{l}\text { REKRUTMEN TENAGA KERJA } \\
\text { BARU SECARA BERKALA }\end{array}$ & $\begin{array}{l}\text { Lebih dari setengahnya }(57,5 \%) \text { stakeholder } \\
\text { menerima tenaga kerja secara incidental. } \\
\text { Sedangkan hampir setengahnya }(42,5 \%) \\
\text { stakeholder menerima tenaga kerja secara } \\
\text { berkala. }\end{array}$ \\
\hline 4 & 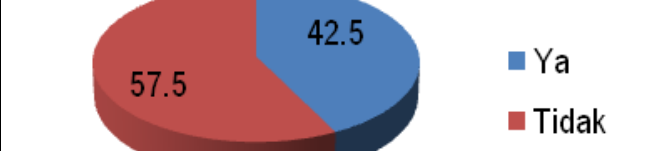 & \\
\hline & $\begin{array}{l}\text { Hampir setengahnya (47,5\%) } \\
\text { stakehorder menyatakan bahwa } \\
\text { bidang studi yang di kuliahkan di } \\
\text { Jurusan PGMI penting. Tetapi } \\
\text { sebagian kecil (35\%) stakehorder } \\
\text { menyatakan bahwa bidang studi } \\
\text { yang di kuliahkan di Jurusan PGMI } \\
\text { tidak penting. Hal ini karena kurang } \\
\text { menunjang langsung dalam } \\
\text { melaksanakan tugas. }\end{array}$ & 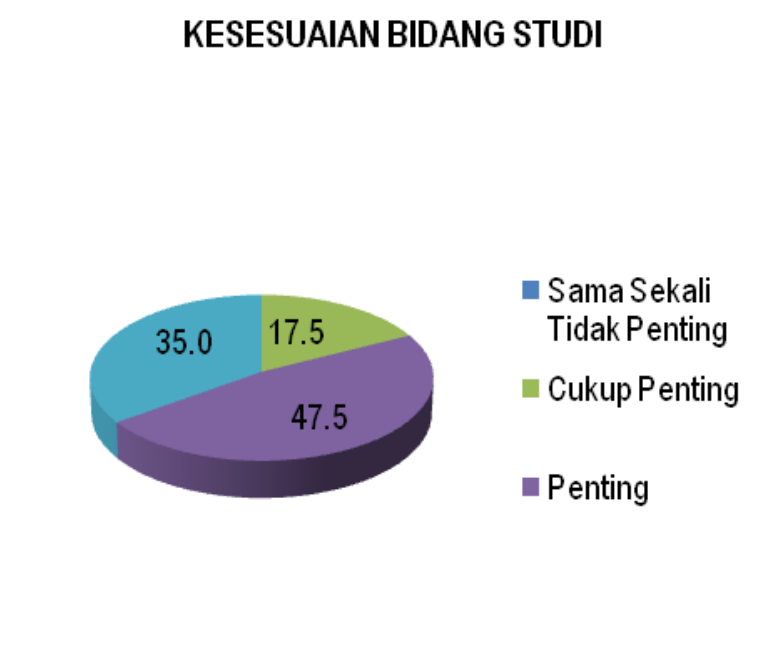 \\
\hline
\end{tabular}




\begin{tabular}{|c|c|c|}
\hline 5 & 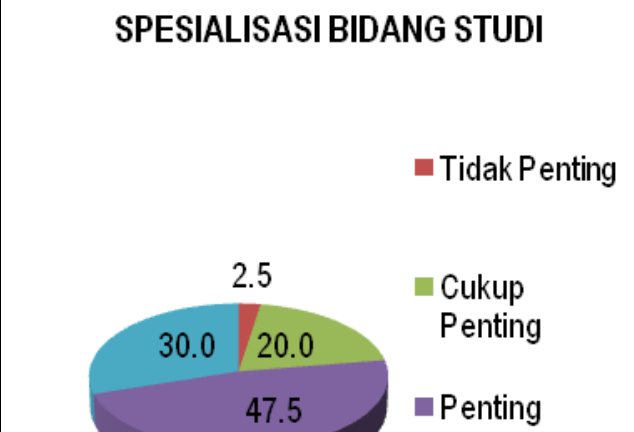 & $\begin{array}{l}\text { Hampir setengahnya }(47,5 \%) \text { stakehorder } \\
\text { menyatakan bahwa spesialis bidang studi } \\
\text { yang dikuliahkan di Jurusan PGMI itu } \\
\text { penting. Hanya sedikit sekali }(2,5 \%) \\
\text { stakehorder menyatakan bahwa spesialis } \\
\text { bidang studi yang dikuliahkan di Jurusan } \\
\text { PGMI itu tidak penting. }\end{array}$ \\
\hline & $\begin{array}{l}\square \text { Sangat } \\
\text { Penting }\end{array}$ & \\
\hline 6 & $\begin{array}{l}\text { Hampir setengahnya }(42,5 \%) \\
\text { stakeholder menyatakan bahwa } \\
\text { prestasi akademik/transkrip nilai } \\
\text { penting dibutuhkan bagi } \\
\text { stakeholder. Sebagian kecil }(37,5 \%) \\
\text { menyatakan bahwa prestasi } \\
\text { akademik/transkrip nilai cukup } \\
\text { penting diutuhkan oleh stakeholder. } \\
\text { Sebagian kecil (20,0\%) stakeholder } \\
\text { menyatakan bahwa prestasi } \\
\text { akademik/transkrip nilai sangat } \\
\text { penting dibutuhkan bagi } \\
\text { stakeholder. }\end{array}$ & 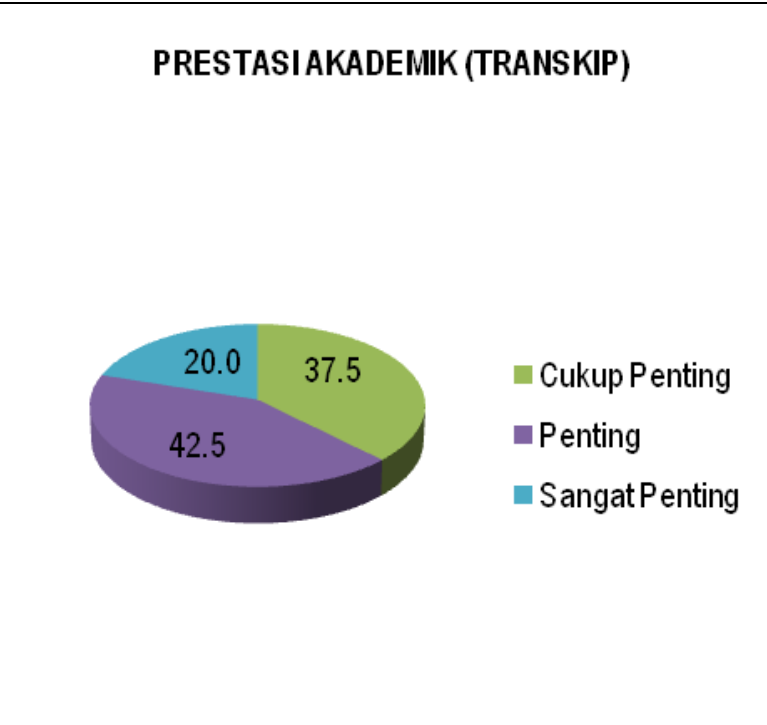 \\
\hline
\end{tabular}




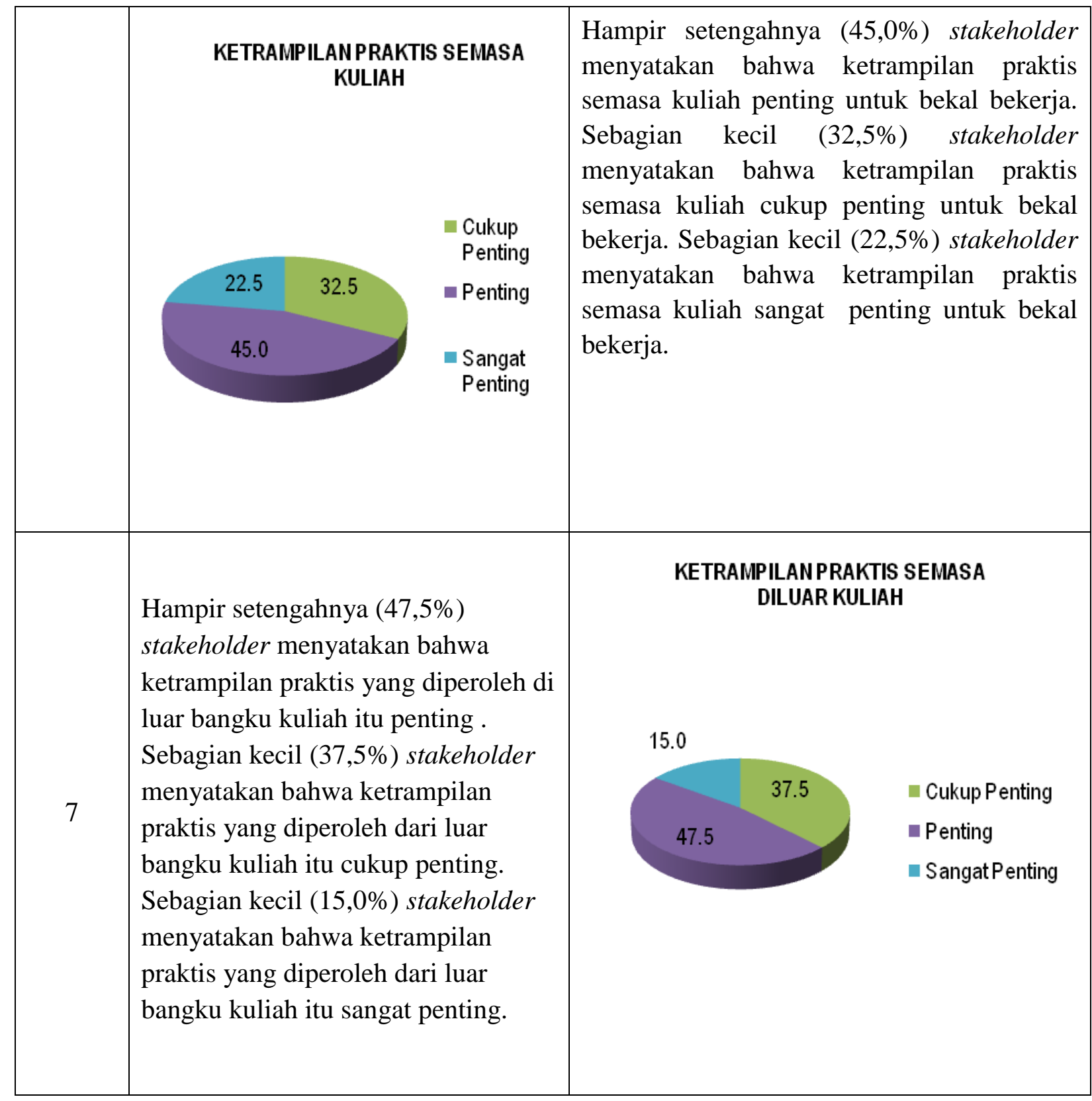




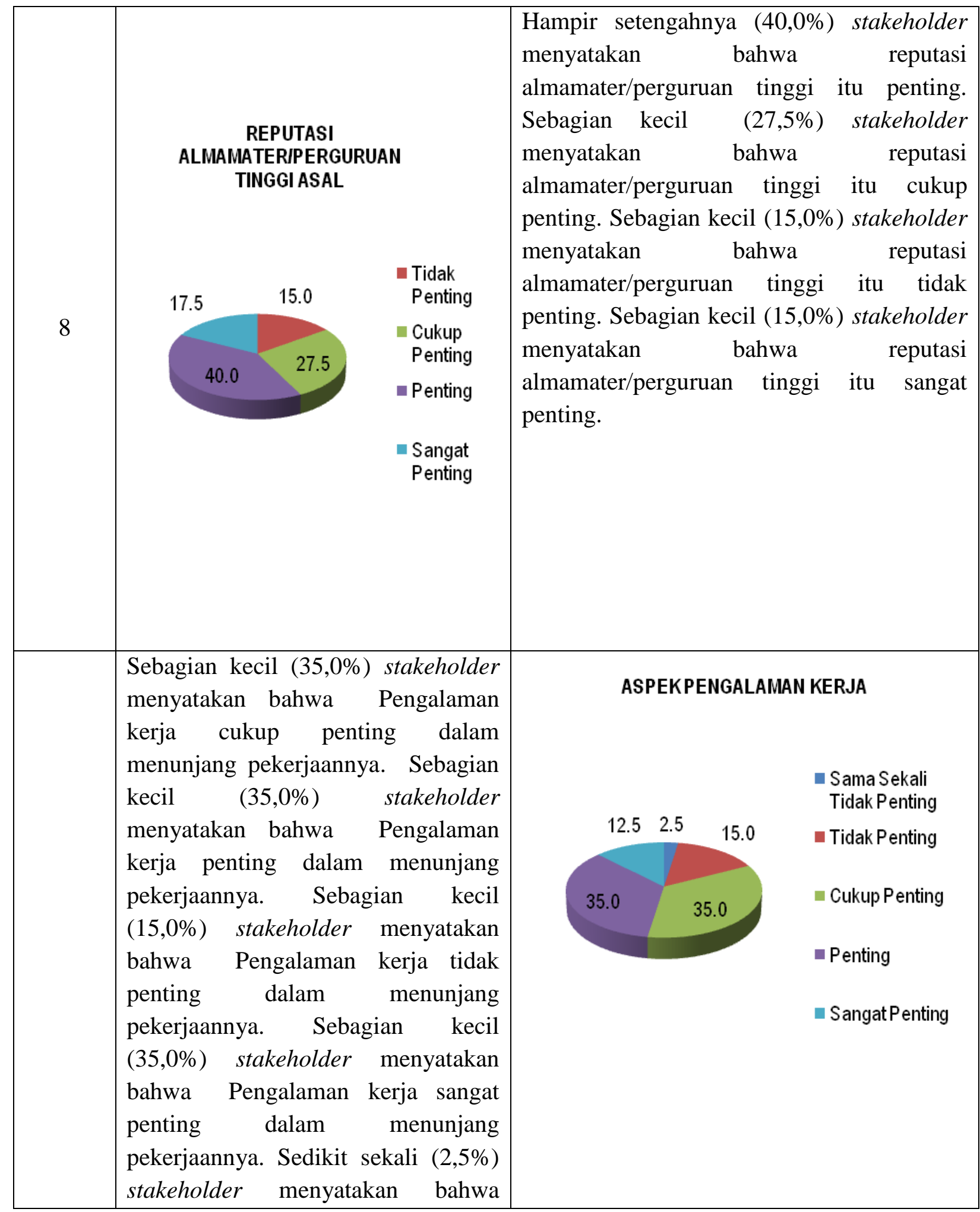




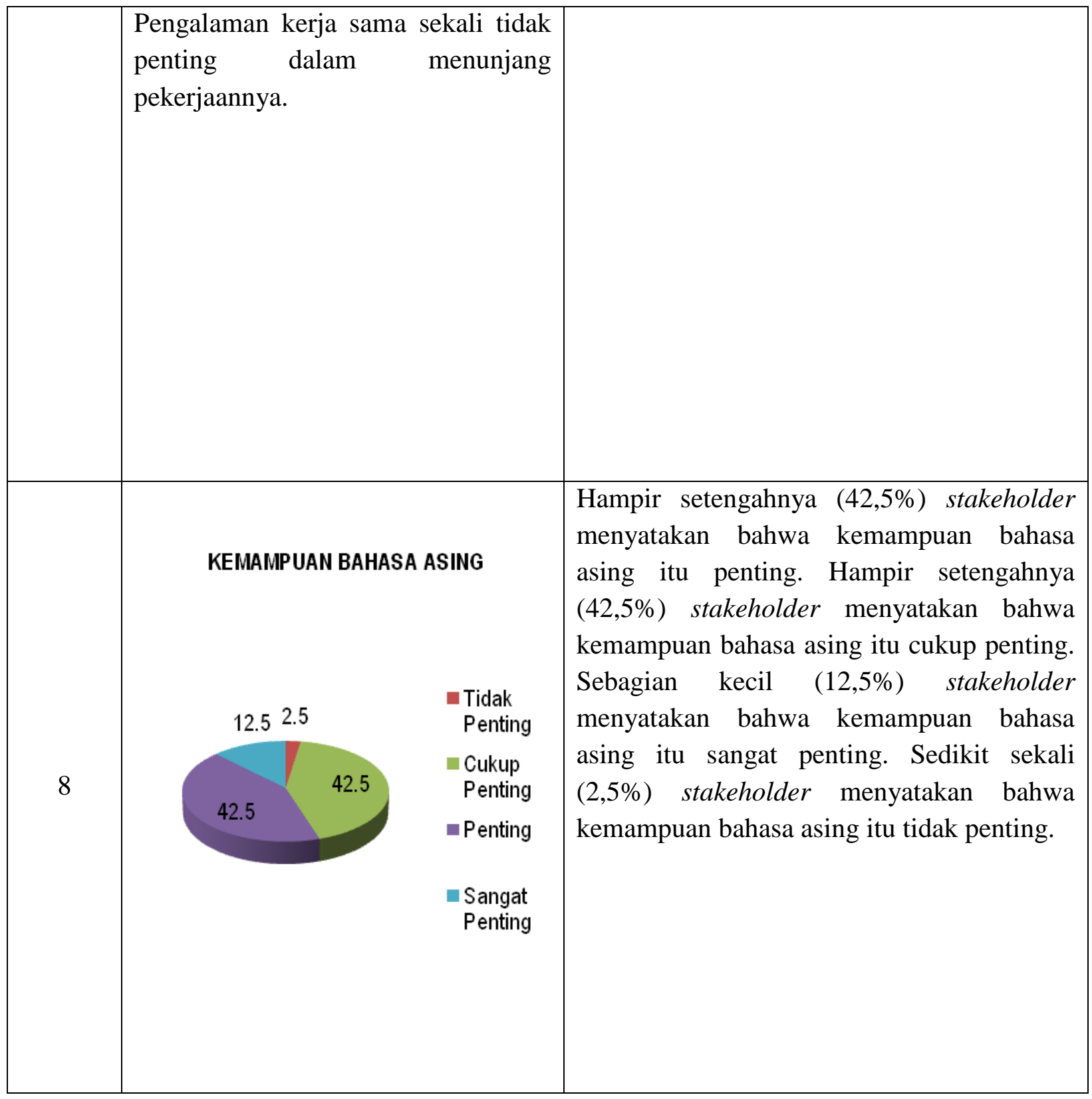




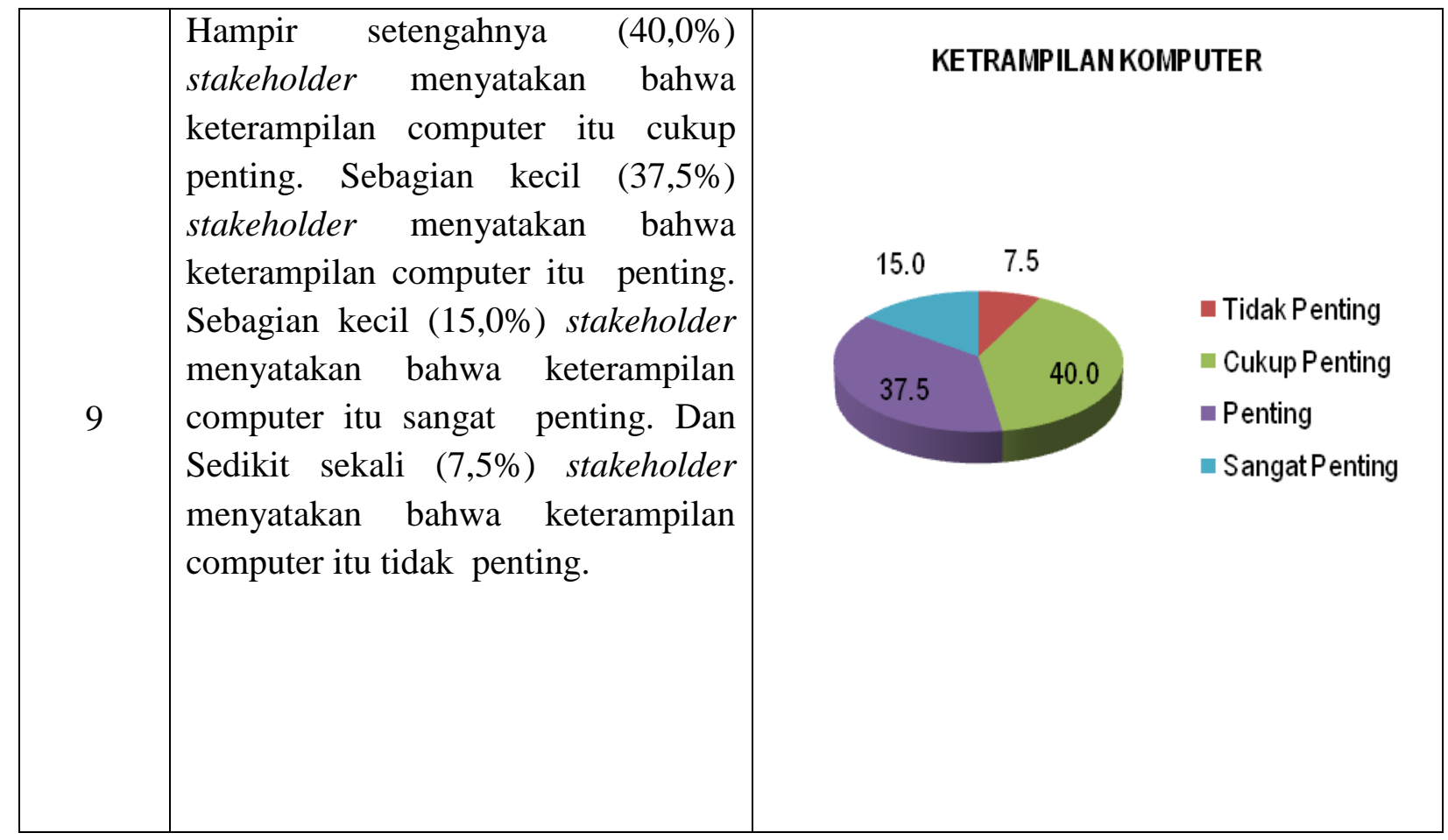

\section{Pembahasan}

\section{a. Alumni}

\subsection{Pekerjaan}

Hampir setengahnya (40\%) alumni mendapat pekerjaan kurang dari tiga bulan setelah wisuda, Hampir setengahnya juga (40\%) alumni mendapatkan pekerjaan atas informasi dari temannya. Sebagian besar $(88,9 \%)$ alumni mendapat pekerjaan sesuai dengan bidang studinya dan hampir setengahnya $(46,7 \%)$ diterima kerja tanpa tes. Sebagian besar $(82,2 \%)$ alumni menyatakan bahwa penguasaan bahasa asing bukan syarat utama. Begitu juga dengan penguasaan software aplikasi dan komunikasi tidak menjadi syarat utama juga.

Sebagian besar (80\%) alumni tidak pernah mengikuti kegiatan alumni di almamaternya dan bahkan lebih dari setengahnya $(68,9 \%)$ alumni tidak memberikan informasi perihal lowongan pekerjaan kepada almamaternya khususnya kepada mahasiswa yang PPL di lokasi alumni bekerja. 
Mata kuliah kependidikan dan keislaman dianggap oleh alumni relevan dengan pekerjaannya. Ada juga beberapa mata kuliah yang dianggap kurang relevan dengan pekerjaannya secara langsung, yaitu mata kuliah filsafat, pendidikan multicultural dan ilmu kalam.

Masalah yang dihadapi oleh alumni dalam menghadapi pekerjaan misalnya : formasi CPNS sangat sedikit sekali dan bahkan terganjal oleh akreditasi jurusan, banyak alumni dari jurusan yang sama tetapi dari perguruan tinggi yang berbeda sehingga menjadikan saingan dalam lowongan kerja. Tidak adanya networking, kurang informasi tentang dunia kerja serta tingkat kepercayaan stakeholder terhadap LPTK yang salah satunya IAIN Syekh Nurjati Cirebon yang menurun.

\subsection{Penyelenggaraan Pendidikan dan Pembelajaran}

Lebih darisetengahnya (57,8\%)alumni menyatakan bahwa kegiatan akademik secara umum dijurusan PGMI berjalan baik. Hamper setengahnya $(44,4 \%)$ alumni menyatakan bahwa kompetensi dosen PGMI baik. Lebih daarisetengahnya juga (66,7\%)alumni menyatakan bahwa pelayanan bimbingan akademik berjalan baik.

Hampir setengahnya (48,9\%) alumni menyatakan bahwa matakuliah yang bersifat praktek itu sudah baik. Hampir setengahnya (44,4\%) alumni menyatakan pernah terlibat dalam penelitian dosen.

Hanya sebagian kecil $(35,6 \%)$ alumni menyatakan bahwa sarana dan prasarana kampus itu baik. Lebih dari setengahnya $(71,1 \%)$ alumni menyatakan bahwa pelayanan registrasi akademik awal mahasiswa baik. Sedangkan pelayanan IT masih kurang baik. Hamper setengahnya (40,0\%) alumni menyatakan pelayanan perpustakaan masih kurang baik.

Rata-rata sebagian besar alumni menyatakan bahwa intensif bahasa, praktek ibadah, bimbingan PPTQ, ujian Komprehenship, PPL, seminar proposal, pelaksanaan wisuda semua dinyatakan baik dalam pelaksanaannya. 
Masukan dan saran dari alumni bahwa Sebagian kecil (17,8\%) responden memberikan saran dan masukan ke kampusnya tentang ruang belajar yang representative dan memadai. Sebagian kecil (16,7\%) responden memberikan masukan tentang Peningkatan kualitas lulusan. Sebagian kecil (14,4\%) responden memberikan masukan tentang Peningkatan pelayanan akademik di fakultas/keramahan. Sebagian kecil $(13,3 \%)$ responden memberikan masukan tentang Peningkatan sarana dan prasana. Sebagian kecil $(11,1 \%)$ responden memberikan masukan tentang Peningkatan praktek mengajar. Sebagian kecil $(14,4 \%)$ responden memberikan masukan tentang Peningkatan pelayanan perpustakaan. Sebagian kecil $(15,6 \%)$ responden memberikan masukan tentang Peningkatan kualitas dosen. Sedikit sekali (2,2\%) responden memberikan masukan tentang penghapusan unsur nepotisme.

\section{b. Stakeholder}

Lebih dari setengahnya (65.0\%) stakeholder sebagai tempat bekerja alumni PGMI adalah swasta. hanya sebagian kecil (35,0\%) stakeholder yang sebagai tempat bekerja alumni adalah negeri. Lebih dari setengahnya (65\%) tenaga kerja yang ada di stakeholder berjumlah antara 10 sampai 50 orang. Sebagian kecil (35\%) tenaga kerja yang ada di stakeholder berjumlah sekitar 10 orang Hampir setengahnya $(47,5 \%)$ stakeholder Penerimaan tenaga kerja dari lamaran langsung dari pelamar. Hampir setengahnya (42,5\%) stakeholder juga menerima tenaga kerja dari iklan di media masa. Hanya sebagian kecil $(10,0 \%)$ stakeholder meneima tenaga kerja dari informasi yang terbatas.

Sebagian besar $(85,0 \%)$ stakehorder dalam meneyeleksi tenaga kerja baru dengan cara seleksi sendiri artinya tidak melibatkan fihak luar instansi. Sedangkan sebagian kecil $(15,0 \%)$ stakehorder menyeleksi tenaga barunya dengan system magang. 
Lebih dari setengahnya $(57,5 \%)$ stakeholder menerima tenaga kerja secara incidental. Sedangkan hampir setengahnya $(42,5 \%)$ stakeholder menerima tenaga kerja secara berkala.

Hampir setengahnya (47,5\%) stakehorder menyatakan bahwa bidang studi yang di kuliahkan di Jurusan PGMI penting. Tetapi sebagian kecil (35\%) stakehorder menyatakan bahwa bidang studi yang di kuliahkan di Jurusan PGMI tidak penting. Hal ini karena kurang menunjang langsung dalam melaksanakan tugas.

Hampir setengahnya (47,5\%) stakehorder menyatakan bahwa spesialis bidang studi yang dikuliahkan di Jurusan PGMI itu penting. Hanya sedikit sekali (2,5\%) stakehorder menyatakan bahwa spesialis bidang studi yang dikuliahkan di Jurusan PGMI itu tidak penting.

Hampir setengahnya (42,5\%) stakeholder menyatakan bahwa prestasi akademik/transkrip nilai penting dibutuhkan bagi stakeholder. Sebagian kecil (37,5\%) menyatakan bahwa prestasi akademik/transkrip nilai cukup penting diutuhkan oleh stakeholder. Sebagian kecil (20,0\%) stakeholder menyatakan bahwa prestasi akademik/transkrip nilai sangat penting dibutuhkan bagi stakeholder.

Hampir setengahnya (45,0\%) stakeholder menyatakan bahwa ketrampilan praktis semasa kuliah penting untuk bekal bekerja. Sebagian kecil (32,5\%) stakeholder menyatakan bahwa ketrampilan praktis semasa kuliah cukup penting untuk bekal bekerja. Sebagian kecil $(22,5 \%)$ stakeholder menyatakan bahwa ketrampilan praktis semasa kuliah sangat penting untuk bekal bekerja.

Hampir setengahnya (47,5\%) stakeholder menyatakan bahwa ketrampilan praktis yang diperoleh di luar bangku kuliah itu penting. Sebagian kecil $(37,5 \%)$ stakeholder menyatakan bahwa ketrampilan praktis yang diperoleh dari luar bangku kuliah itu cukup penting. Sebagian kecil (15,0\%) stakeholder 
menyatakan bahwa ketrampilan praktis yang diperoleh dari luar bangku kuliah itu sangat penting.

Hampir setengahnya (40,0\%) stakeholder menyatakan bahwa reputasi almamater/perguruan tinggi itu penting. Sebagian kecil (27,5\%) stakeholder menyatakan bahwa reputasi almamater/perguruan tinggi itu cukup penting. Sebagian kecil (15,0\%) stakeholder menyatakan bahwa reputasi almamater/perguruan tinggi itu tidak penting. Sebagian kecil (15,0\%) stakeholder menyatakan bahwa reputasi almamater/perguruan tinggi itu sangat penting.

Sebagian kecil $(35,0 \%)$ stakeholder menyatakan bahwa Pengalaman kerja cukup penting dalam menunjang pekerjaannya. Sebagian kecil $(35,0 \%)$ stakeholder menyatakan bahwa Pengalaman kerja penting dalam menunjang pekerjaannya. Sebagian kecil (15,0\%) stakeholder menyatakan bahwa Pengalaman kerja tidak penting dalam menunjang pekerjaannya. Sebagian kecil (35,0\%) stakeholder menyatakan bahwa Pengalaman kerja sangat penting dalam menunjang pekerjaannya. Sedikit sekali (2,5\%) stakeholder menyatakan bahwa Pengalaman kerja sama sekali tidak penting dalam menunjang pekerjaannya.

\section{Kesimpulan}

1. Keberadaan alumni jurusan PGMI yang meurpakan responden seluruhnya 45 orang dengan rincian : sebanyak $75,6 \%$ adalah laki-laki dan $24,4 \%$ perempuan. Adapun responden yang lulus tahun 2012 sebanyak 51,2\% dan yang lulus pada tahhun 2013 sebanyak 48,8\%. Dengan asal domisili responden sebanyak 53,3\% dari Kab. Cirebon, sebanyak 28,9\% berasal dari Kab, Kuningan, sebanyak 11,1\% berasal dari Kab. Majalengka, sebanyak 4,4\% berasal dari luar wilayah III Cirebon dan sebanyak 2,2\% berasal dari Kotamadya Cirebon. Adapun status 
responden sebanyak $84,4 \%$ mengajar di sekolah swasta dan sebanyak 15,6\% mengajar di sekolah negeri.

2. Profil kompetensi dan keterampilan lulusan jurusan PGMI yaitu : Hampir setengahnya (40\%) alumni mendapat pekerjaan kurang dari tiga bulan setelah wisuda, Hampir setengahnya juga (40\%) alumni mendapatkan pekerjaan atas informasi dari temannya. Sebagian besar $(88,9 \%)$ alumni mendapat pekerjaan sesuai dengan bidang studinya dan hampir setengahnya $(46,7 \%)$ diterima kerja tanpa tes. Sebagian besar $(82,2 \%)$ alumni menyatakan bahwa penguasaan bahasa asing bukan syarat utama. Begitu juga dengan penguasaan software aplikasi dan komunikasi tidak menjadi syarat utama juga.

3. Relevansi pelaksanaan kurikulum dan kebutuhan pasar kerja khususnya yang dilakukan oleh IAIN SNJ misalnya telah mengupayakan misalnya dengan melayani registrasi kepada mahasiswa, bimbingan intensif bahasa,praktek ibadah, PPTQ, PPL dan KKN dengan maksimal serta selalu menggunakan kurikulum yang sesuai dengan tuntutan stakeholder.

4. Dalam rangka memenuhi Akreditasi/sertifikasi, Jurusan PGMI selalu berusaha maksimal baik dalam bidang akademik, penelitian dan pengabdian kepada masyarakat. Misalnya menddorong dosennya untuk melanjutkan pendidikan ke s3 dan berinovasi dalam proses pembelajaran, mengikutsertakan dosennya dalam berbagai penelitian, penulisan buku daras, seminar dan workshop. Melaksanakan berbagaikegiatan pengabdian kepada masyarakat baik yang diadakan secara terjadwal oleh lembaga maupun secara incidental yang diketahui oleh lembaga.

\section{DAFTAR PUSTAKA}

BAN -PT,'Naskah Akademik, Akreditasi institusi Perguruan Tinggi”

Borang Akreditasi Jurusan PGMI Fakultas Tarbiyah IAIN Syekh Nurjati Cirebon,2011 
Dikti, 2008, "Wardiman Kembali Ingatkan Link and Match" Millington,Claire.,2006

"The Use of Tracer studies for Enhancing Relevance and Marketability in Online and Distance Education. "BarbadosCommunity College.

Nana Sudjana dkk, 1989:57 Metodologi Penelitian, Rosda Karya Bandung.

Setneg, 2010 ; Mengharmonisasikan Tenaga kerja dan pendidikan di Indonesia.

Undang-undang RI Nomor 14 tentang Guru dan Dosen

Undang-undang RI Nomor 20 Tahun 2003 tentang Sisdiknas.

http://blog.uin-malang.ac.id/muttaqin/2010/11/28/10/ 